\title{
FACTORS AFFECTING THE FLOW TIME OF PRESENTATION OF FINANCIAL STATEMENTS
}

(Case Study of Banking Companies Listed on Indonesia Stock Exchange in 2016-2017)

Wikan Budi Utami, Sausan Devi Ratih

Tax Management Study Program, ITB AAS Indonesia

\begin{abstract}
This study aims to determine the factors that influence the time span of the presentation of financial statements on banking companies listed on the Indonesia Stock Exchange in 2016-2017. The factors that are suspected to influence the time span of the presentation of financial statements on banking companies listed on the Indonesia Stock Exchange in 2016-2017 in this study are solvency, profitability and company size. The sampling method uses a purposive sampling method of 52 sample banking companies. The results of this study indicate that solvency has no significant effect on the time span of financial statement presentation with a calculated value of $1.728<\mathrm{t}$ table 2.00958 and has a significant level of $0.091>\alpha=0.05$. Profitability has a significant effect on the time span of the presentation of financial statements with a significant value of $0.041<\alpha=0.05$ and $t$ count value of $2.679>\mathrm{t}$ table 2.00958. The size of the company has no significant effect on the time span of financial statement presentation with a significant level of $0.066>\alpha=0.05$ and $t$ count value $1.880<\mathrm{t}$ table 2.00958. Simultaneously shows that company size, profitability, and solvency have a significant effect on the time span of financial statement presentation with a calculated $F$ value of 5.159> F table 3.18 and a significance value of $0.004<\alpha=0.05$.
\end{abstract}

Keywords: company size, profitability, and solvency

\section{Introduction}

The financial statements are a structured presentation of the financial position and financial performance of the entity. Financial statements are accounting information that reflects the amount of wealth of a company. The purpose of the financial statements themselves provide information in the form of financial position, financial performance and cash flow of the entity that can be useful for users of financial statements in making economic decisions (PSAK 1, 2016). In an effort to meet the information needs needed by investors, the company's management has an obligation to publish financial reports at least once a year. Through the issuance of these financial statements the company can inform financial performance that is expected to be beneficial, especially for shareholders. The main condition desired by investors to be willing to channel funds is a feeling of security in investment, where the feeling of security is obtained from clear, reasonable and timely information (Daniati and Suhairi, 2006).

Financial statements must be presented on time, because with the inaccuracy of financial statements will be bad for the company both directly and indirectly. Timeliness of reporting is needed by the users of financial statements, users not only need to have financial information that is relevant to their predictions and decisions, but the information must be more new, and not only related to the past period. Financial statements are very useful for the wearer, so the 
financial statements must meet eight requirements, namely to be able to understood, relevant, reliability, comparable, testable, neutral, timely and complete (Sujarweni, 2017).

Solvency according to Kasmir (2012) is the ability of a company to fulfill all financial obligations when the company is liquidated. The results of Heru Setiawan's research (2013) show that solvency affects audit delay. This is because the level of the size of the debt owned by the company will cause the examination and reporting of the company's debt inspection take longer so that it can slow down the audit reporting process by the auditor. In contrast to the results of Fitria Ingga's study (2015) which shows that solvency does not affect audit delay. This is because both companies that have large total debts with companies that have small total debts will not affect the process of completing the financial statement audit, because the appointed auditor must have provided the time as needed to complete the debt auditing process.

Profitability is the company's ability to get profits through all the company's capabilities, and existing sources such as sales activities, cash equity, number of employees, and so on (Harahap, 2009). Adi Nugraha's research results (2013) showed that profitability significantly affected audit delay. This can be interpreted that companies that have a high level of profitability require faster time in auditing financial statements. This is because companies must deliver good news as soon as possible to the public. In contrast to the results of the study of Andi Kartika (2009) which showed that profitability did not significantly influence audit delay. This is because the audit process of companies that have a low level of profitability is not different from the audit process of companies with high levels of profitability, because companies with high or low profitability will tend to speed up the audit process.

The size of the company according to Rochimawati (2010) is a measure that shows the size or size of a company that is characterized by several measures including total sales, total assets, log size, number of employees, company market value, and book value of the company. The results of the research by Ketut Dian and Made Yeni (2014) said that the larger the size of the company, the shorter the audit delay. This is because the bigger the company, the company has a good internal control system so that it can reduce the error rate of financial statements, and then make it easier for auditors to audit the financial statements. Kusuma (2017), Budiyono (2017), found that profitability affected the financial statement. In contrast to the results of the research of Dewi Lestari (2010) which shows that company size has no effect on audit delay. This is because companies with large and small sizes have the same possibility in facing pressure over the submission of financial statements. In addition, the auditor considers that in the auditing process, both large and small companies will be examined in the same manner in accordance with procedures in the professional standards of public accountants.

\section{Literature Review}

\subsection{Financial Statements}

Financial Accounting Standards (SAK, 2016) explain that financial statements are structured presentations starting from the financial position and financial performance of an entity. In the financial statements provide information about the economic resources of the reporting entity, claims against reporting entities, and the impact of transactions and events and other conditions that change these resources and claims. In the Basic Framework for the Preparation and Presentation of Financial Statements, Financial Accounting Standards (SAK, 2016) state that there are four qualitative characteristics of financial statements that are useful for its users. The four qualitative characteristics of financial statement information are:

a. Can be understood (understandability) The information contained in financial statements can 
be understood by users and expressed in terms and terms that are tailored to the limits of understanding of users. Users are assumed to have adequate knowledge of the activities and operating environment of the reporting entity, as well as the willingness to learn the information in question.

b. Relevant Financial statements are relevant information to meet users in decision making. Information has relevant quality if it can influence users' economic decisions by helping them evaluate past, present or future events, helping to correct their evaluation results in the past.

c. Reliable Information in financial statements must be free from misleading notions and material errors, present every fact that occurs honestly, and be verifiable. Information may be relevant, but if the nature of its presentation cannot be relied on then the use of the information could potentially be misleading.

d. Can be compared The information contained in the financial statements will be more useful if it can be compared with the financial statements of the previous period or the financial statements of other reporting entities in general. Comparisons can be done internally and externally. Internal comparisons can be made if an entity applies the same accounting policy from year to year. Externally comparisons can be made if the entity being compared applies the same accounting policy. If a government entity adopts an accounting policy that is better than the current accounting policy, the change is disclosed in the period in which the change occurs.

\subsection{Timeliness}

Timeliness that the financial statements must be presented at regular intervals to show changes in company circumstances which in turn might affect the user's predictions and decisions. Timeliness also shows the time span between presenting the desired information and the frequency of information reporting. Timely information is influenced by the ability of managers to respond to every event or problem. If the information is not delivered in a timely manner it will cause the information to lose value in supporting managers to deal with uncertainties that occur in their work environment (Kadir, 2011).

Relevant information will be useful for users if it is available on time before the user loses the opportunity or ability to influence the decision to be taken. Timeliness shows the time span between presenting the desired information and the frequency of information reporting. Timeliness is measured in the interval between the year the company period ends and the date when the financial statements are issued with the financial year deadline (Mouna, 2013). One way to measure transparency and quality of financial statements is timeliness. The time span between the date of the company's financial statements and the date when the financial information is announced by the public is related to the quality of the financial information reported. Based on the Basic Framework for the Preparation and Presentation of Financial Statements of Financial Accounting Standards, financial statements must meet four qualitative characteristics that are characteristic that make financial statement information useful for its users

These four characteristics are understandable, relevant, reliable, and comparable. To obtain relevant information, there are several obstacles, one of which is the timeliness constraint (Puspaningrum, 2013).

According to Dyer and Mc Hugh (1975) there are three criteria for delays in seeing the timeliness of financial reporting, namely: 
a. Preliminary Lag: interval of the number of days between the date of the financial statements to the receipt of the final preliminary report by the exchange.

b. Auditor's Report Lag: interval of the number of days between the date of the financial statements to the date the auditor's report is signed.

c. Total Lag: interval of the number of days between the date of the financial statements to the date of receipt of the report published by the exchange.

In this study, the Audit Report Lag will be used to determine the timeliness of companies in submitting audited financial statements to the public. Audit Report is one of the external audit variables observed, so outsiders can measure the efficiency of the audit because it is related to the timeliness of the audit and the timeliness of the delivery of company financial information. Timeliness of financial reporting is very important for internal and external parties of the company. the longer the delivery of financial statement information, the benefits will be increasingly useless. The reputation of the company will be at stake, if the submission of financial statements is late (Susianto, 2017).

\subsection{Solvency}

Solvency according to Kasmir (2012) is the ability of a company to fulfill all financial obligations when the company is liquidated. Some ratios to measure the company's solvency include:

a. Debt to Total Asset Ratio (DAR).

DAR according to Sawir (2008) is a ratio that shows the proportion between liabilities owned by all assets owned. According to Riyanto (2010), the formula for calculating DAR can be calculated as follows: DAR $=$ (Total Debt) $/$ (Total Assets)

This Debt Ratio calculates how far the funds provided by the creditor. The high ratio of total debt to total assets indicates that the company uses high financial leverage. The use of high financial leverage will increase the profitability of share capital (Return On Equity) quickly. However, on the other hand if sales decline the profitability of share capital will decrease.

b. Debt To Equity Ratio

Debt to Equity Ratio (DER) is one of the leverage ratios (solvency) that measures the ratio between external capital and own capital. According to Kasmir (2013: 157) the debt to equity ratio (DER) is: "Debt to Equity Ratio is a raso used to assess debt with equity. To find this ratio by comparing between all debt, including current debt and all equity".

DER $=($ Total Debt $) /($ Total Equety $)$

Companies that have a high leverage ratio can have an impact on the emergence of a greater risk of loss, but also have the opportunity to get a large profit. The higher the leverage ratio assumes that the higher the proportion of debt the company has. According to Juniati (2016) leverage is the company's ability to repay all of its debts both short-term debt and longterm debt. The existence of a lot of debt ownership by companies is considered that the company still gets a lot of trust from the public, especially the finance parties because it is able to obtain a lot of debt, besides that with high debt the company also has a lot of assets so that it is able to run its business (Dewayani et al, 2017 ). This encourages companies to submit their financial statements in a timely manner, because they want to immediately inform the public that the trust of the finance parties to the company is still high and the company has large assets to carry out its business, in accordance with the existing obligations that the company as an agent must be timely in delivering the information it has to the public as the principal so that it can be used as a basis for decision making. 


\subsection{Profitability}

Profitability is a ratio that shows how capable the company is in generating profits, both from existing sales and from total assets owned based on information contained in the income statement (Paransa, 2016). Profitability is one indicator of a company's success to be able to generate profits so the higher the profitability, the higher the company's ability to generate profits for the company. Profitability shows the level of efficiency and performance of the company in generating profits for shareholders (Susilo and Fatmeyati, 2016). According to Irham Fahmi (2016) in general there are 4 (four) profitability ratios including the following:

a. Gross Profit Margin

The gross profit margin ratio is the gross profit margin. Regarding gross profit margin Lyn M. Fraser and Aileen Ormiston gave their opinion that is, "Gross profit margin, which shows the relationship between sales and cost of goods sold, measures the ability of a company to control inventory costs or operating costs of goods as well as to continue price increases through sales to customer." Or further, Joel G. Siegel and Jae K. Shim said that, "Percentage of the remainder of the sale after a company pays for the goods; also called the gross profit margin. The gross profit margin ratio formula is: Gross Profit Margin $=($ Sales - Cost of good sold) / Sales

b. Net Profit Margin

The ratio of net profit margin is also called the ratio of income to sales. Regarding this profit margin Joel G. Siegel and Jae K. Shim said, "(1) Net profit margin is equal to net income divided by net sales. This shows the stability of the unity to produce gains at a special sales level. By providing a company's profit margins and industry norms in previous years, we can assess the efficiency of operations and pricing strategies as well as the status of the company's relationships with other companies in the industry. (2) Gross profit margin is equal to gross profit divided by net profit. High profit margins are preferred because they show that the company gets good results that exceed the cost of goods sold ". The net profit margin ratio formula is Net Profit Margin $=($ Earning after tax $($ EAT $)) /$ Sales

c. Return On Investment (ROI)

The ratio of return on investment (ROI) or return on investment, that in some other references this ratio is also written with the return on total assets (ROA). This ratio sees the extent to which investments that have been invested are able to provide a return on profits as expected. And the investment is actually the same as the company's assets that are invested or placed. As for the formula used is ROI = EAT / (Total Assets)

\subsection{Prior Research}

Previous studies have been carried out, including:

Yusraiaini, Restu Agusti, and Livia Dara Raesya (2010) conducted a study entitled Analysis of Factors Affecting the Timeliness of Submitting Financial Statements to the Public on Companies Listed on the Indonesia Stock Exchange (2005-2007) with the independent variables studied consisted of company size, profitability, solvency, liquidity, company age, contingent items, opinions with dependent variables are the timeliness of financial reporting. The test results show that company size, profitability, liquidity and age of the company do not affect the timeliness of financial reporting. The test results show that contingencies and audit opinions have an influence on the timeliness of financial reporting 
Penelitia Listyorini Wahyu Widati and Fina Septy (2008) with the title Factors Affecting the Time Span of Presentation of Financial Statements to the Public (Empirical Study of LQ 45 Companies Listed on the Indonesia Stock Exchange) with variable size, profitability, solvency, auditor's reputation , auditor's opinion. The results showed that the auditor's reputation and reputation had no effect on the timeliness of financial reporting while the size, profitability and audit opinion had an influence on the timeliness of financial reporting. (Empirical Study on LQ 45 Companies Listed on the Indonesia Stock Exchange) with variable size, profitability, solvency, auditor's reputation, auditor's opinion. The results showed that the auditor's reputation and reputation had no effect on the timeliness of financial reporting while the size, profitability and audit opinion had an influence on the timeliness of financial reporting.

Christina Dwi Astuti (2007) conducted a study entitled The Factors Affecting the Timeliness of Financial Reporting, with the independent variables studied consisting of company size, profitability, leverage, public ownership structure, company age, reputation of auditor opinion with the dependent variable being accuracy financial reporting time. The test results show that leverage, profitability, and age of the company do not affect the timeliness of financial reporting and company size, ownership structure both outside and inside, auditor reputation and audit opinion have an influence on the timeliness of financial reporting.

\subsection{Framework for Thinking}

The framework of thought appears in figure 1 below

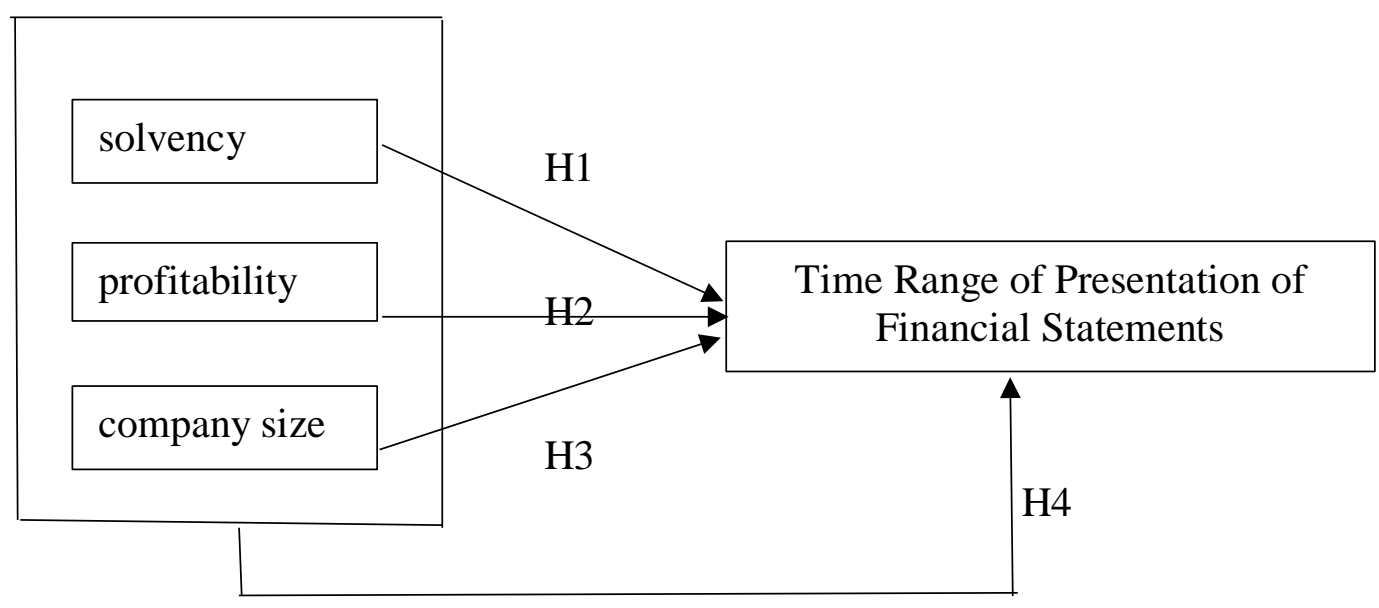

\subsection{Hypothesis}

a. Solvency partially has a significant effect on the time span of presenting financial statements in service companies, the financial sector, bank sub-sectors listed as public companies on the Indonesia Stock Exchange (BEI) in 2016-2017.

b. Profitability partially has a significant effect on the time span of the presentation of financial statements in service companies, the financial sector, sub-sectors of banks listed as public companies on the Indonesia Stock Exchange (BEI) in 2016-2017.

c. The size of the company partially has a significant effect on the time span of the presentation of financial statements in service companies, the financial sector, sub-sectors of banks listed as public companies on the Indonesia Stock Exchange (BEI) in 2016-2017. 
d. Firm size, profitability, and solvency simultaneously have a significant effect on the time span of presenting financial statements in service companies, financial sectors, bank subsectors listed as public companies on the Indonesia Stock Exchange (BEI) in 2016-2017.

\section{Research Methodology}

This type of research is quantitative descriptive that is data obtained from a sample of the study population analyzed quantitatively using descriptive statistics so that it can be concluded that the hypothesis is proven or not (Sugiyono, 2015).

\subsection{Data Sources, Populations, Samples, Data Collection Methods}

The type of data used in this research is secondary data obtained from Financial Statements which have been published on the Indonesia Stock Exchange (BEI) in 2016-2017. The data used in this study were obtained from the Indonesia Stock Exchange (IDX) website, namely www.idx.co.id and related company websites.

The population in this study are banking companies listed on the Indonesia Stock Exchange (IDX) in 2016-2017. The technique used for sampling in this study is the purposive sampling method, with a predetermined limitation that is the company that did not experience losses. From 26 banking companies over a period of 2 years 52 samples were obtained.

\subsection{Research Variables and Operational Definition Variables}

In this study the dependent variable is the time span of presenting the financial statements measured quantitatively in number of days, is the period between the closing date of the financial year to the date stated on the independent auditor's report.

In this study the independent variables are solvency, profitability, company size.

Solvency is an independent variable that shows the company's ability to meet long-term obligations when the company is dissolved. Solvency is proxied through a Debt to Total Assets Ratio (DAR) ratio measured by total debt consisting of current liabilities (short-term) and long-term liabilities, divided by total assets at the end of the financial year of each sample company.

Profitability shows the ability of companies to use assets held to generate income. Profitability is proxied through the ratio of Return on Assets (ROA), i.e. Net Profit divided by Total Assets.

Company size is measured based on total assets / total number of assets owned by each sample company. Variable size of the company is measured by natural logarithm of the total asset value of all samples for 2 years.

\section{Results And Discussion}

\subsection{Classical Assumption Test Results}

a. Normality test

Testing for normality using Kolmogorov Smirnov shows that the significance value of 0.467 is greater than $\alpha=0.05$. This shows that the data distribution is normal.

b. Multicollinearity Test

The results of the normality test value of tolerance for solvability-free variables are 0.652 , profitability is 0.879 and company size is 0.663 and or greater than 0.10 . Meanwhile, the variable VIF value is smaller than 10.00 , namely the size of the company 1.507 , profitability 1.137 , and solvency 1.535 . So it can be concluded that there is no multicollinearity between independent variables. So this regression model is feasible to use. 
c. Autocorrelation Test

To detect the presence or absence of autocorrelation, a Run Test is performed which results in the Asymp value. Sig. (2-tailed) of $0.401>\alpha=0.05$ concluded that autocorrelation symptoms did not occur

d. Heteroscedasticity Test

Based on Scatterplots output it is known that spread points are below and above or around 0 , the points do not collect just above or below it, the spread of the points does not form a wavy pattern widened then narrowed and widened again and the spread of points data points are not patterned. It can be concluded that there is no heterokedasticity problem so that a good and ideal regression model can be fulfilled.

\subsection{Hypothesis Testing Results}

\section{a. Multiple Linear Regression Test}

Based on Table 1 below, a double linear regression equation is obtained as follows: $\mathrm{Y}=$ $151,367-3,547$ X1 + 33,380 X2 - 968.897 X3 + e

b. Significant Test of Individual Parameters ( $t$ Test)

Based on calculations obtained from table 1 , the $t$ value of solvency of $1.728<\mathrm{t}$ table 2.00958 with a significance of $0.091>\alpha=0.05$. So that solvency does not affect the time span of financial statement presentation. The results of this study are consistent with the research of Yusraiaini, Restu Agusti, and Livia Dara Raesya (2010) with a significant value of $0.428>\alpha=0.05$. But contrary to the research of Listyorini Wahyu Widati and Fina Septy (2008), a significant value of $0.026<\alpha=0.05$ so that solvency affects the time span of financial statement presentation.

Based on calculations obtained from the $t$ value of profitability of 2.679>t table 2.00958 with a significance level of $0.041,<\alpha=0.05$ means that profitability has a significant effect on the time span of financial statement presentation. The results of this study are consistent with the results of Listyorini Wahyu Widati's research and Fina Septy (2008), the significance value of $0.026<\alpha=0.05$ which says that profitability affects the time span of financial statement presentation and Ukago (2005), the significance value of $0,0002<\alpha=0.05$ so that profitability influences the the time span of presenting the financial statements. But it is not consistent with the research of Christina Dwi Astuti (2007) which states a significant value of profitability $0.830>\alpha=0.05$ and Yusraiaini, Restu Agusti, and Livia Dara Raesya (2010) with a significant value of 0.942> $\alpha=0.05$ so that profitability has no effect with respect to the time span of presenting financial statements.

Based on calculations obtained from the $t$ value of the company size of $1,880<\mathrm{t}$ table 2.00958 with a significance level of $0.066>\alpha=0.05$. this means that the size of the company has no significant effect on the time span of financial statement presentation. The results of this study are consistent with the research of Ukago (2005), a significant value of $0.0954>\alpha=0.05$ and Livia Dara Raesya (2010) results of a significant value of $0.341<\alpha=0.05$ which states that company size has no effect on the time span presentation of financial statements, but contrary to the results of research Listyorini Wahyu Widati and Fina Septy (2008) which states the significant value of the company size of $0.00<\alpha=0.05$, the results of research Yusraiaini, Restu Agusti, and Christina Dwi Astuti (2007) results significant value of the size of the company is $0.033<\alpha=0.05$ so that the size of the company affects the time span of financial statement presentation. 
Table 1. Summary of Hypothesis Test Results

\begin{tabular}{|l|c|c|c|l|}
\hline \multicolumn{1}{|c|}{ Variable } & $\mathrm{b}$ & $\mathrm{t}$ & Sig & \multicolumn{1}{c|}{ Conclusion } \\
\hline Constans & 151.367 & & & \\
Solvency (X1) & -3.547 & -1.728 & 0.091 & Significantly influential \\
Profitability (X2) & 33.380 & 2.679 & 0.041 & Significantly influential \\
Company size (X3) & -968.897 & -1.880 & 0.041 & Significantly influential \\
\hline F & & 5.159 & 0.004 & Significantly influential \\
\hline $\mathrm{R}^{2}$ & & & 0.244 \\
\hline
\end{tabular}

c. Simultaneous Test (F Test)

From table 1 above the calculated $\mathrm{F}$ value of 5.159> $\mathrm{F}$ table of 3.18 with a significance value of $0.004<\alpha=0.05$ shows that the variables of solvency, profitability, and company size simultaneously have a significant effect on firm value.

d. Coefficient of Determination $\left(\mathbf{R}^{2}\right.$ Test)

The results of the calculation of the regression coefficient in this study obtained an $\mathrm{R}$ Square value of 0.244 . This means that the solvency, profitability and company size variables can explain the time span variable of financial statement presentation by $24.4 \%$ while the remaining $75.6 \%$ is explained by other variables outside the variables examined in this study.

\section{Conclusion}

5.1 The solvency variable has a significant level of $0.091>\alpha=0.05$ and the $t$ value is $1.728<\mathrm{t}$ table 2.00958. These results indicate that the solvency variable has no influence on the time span of financial statement presentation. This means that the length of financial statement submission is not influenced by solvency.

5.2 The profitability variable has a significant level of $0.041<\alpha=0.05$ and the $t$ value is $2.679>\mathrm{t}$ table 2.00958. These results indicate that the profitability variable has a significant effect on the time span of financial statement presentation. This means that the length of financial statement submission is influenced by profitability.

5.3 The firm size variable has a significant level of $0.066>\alpha=0.05$ and the $t$ value is $1.880<\mathrm{t}$ table 2.00958, so H1 is rejected. These results indicate that the firm size variable does not have a significant effect on the time span of financial statement presentation. This means that the length of financial statement submission is not influenced by company size. 


\section{References}

Adi Nugraha. 2013. Factors Affecting Audit Delay. Skripsi.UIN Syarif Hidayatullah Jakarta.

Agnes, Sawir. 2008. Financial Performance Analysis and Financial Planning. Jakarta: PT Gramedia Pustaka Utama.

Andi Kartika. 2009. Factors Affecting Audit Delay in Indonesia (Empirical Study of LQ 45 Companies Registered on the JSX). Journal of Business and Economics Vol. 16 No. 1 Page: 1-17. Semarang Stikubank University.

Factors Affecting Banking Profitability in Indonesia (Studies at Bank BRI, Bank BNI, and Bank BTN)

Cashmere. 2012. Analysis of Financial Statements. Jakarta: PT. Raja Grafindo Persada

Christina Dwi Astuti. 2007. Factors that Affect the Timeliness of Financial Reporting. Journal of Taxation, Accounting and Public Finance Information, Volume 2, Number 1

Daniati, Nina, and Suhairi. 2006. "Influence of Information Content Component of Cash Flow Statement, Gross Profit, Company Size on Stock Expected Return". SNA IX Paper.

Dewayani. Amen and Dewi, V Soraya. 2017. "Analysis of Factors Affecting the Timeliness of Financial Reporting (Empirical Study of Manufacturing Companies Listed on the Indonesia Stock Exchange Period 2011-2016)". The 6th University Research Colloquium 2017, Muhammadiyah University, Magelang. ISSN 2407-9189.

Dewi Lestari (2010). Analysis of Factors Affecting Audit Delay: Empirical Study of Consumer Goods Companies Listed on the IDX. Thesis. Diponegoro University Semarang

Dyer, J.C, and A.J. McHugh. 1975. "The Timeliness of the Australian Annual Report." Journal of Accounting Research, Vol. 13, No.2, pp. 204-219.

Erin Juniati. 2016. Analysis of Factors Affecting the Delay in Submission of Financial Statements to Mining Companies Listed on the Indonesia Stock Exchange for the Period of 2011-2013. JOM Fecon, VOl. 3 No. 1 (February) 2016

Fahmi, Irham. (2016). Introduction to Financial Management. Bandung: ALFABETA, CV.

Fiatmoko, Arizal Latif., And Anisykurlillah. 2015. Factors that are Influence Towards Audit Delay in Banking Companies.Accounting Analysis Journal.

Fitria Ingga. 2015. Effect of Company Size, Company Age, Company Profitability, Company Solvency, Cap Size, and Auditor Opinion on Audit Delay (Case Study on LQ45 Companies Registered on the Indonesia Stock Exchange in 2011-2013). Thesis. Yogyakarta State University. 
Harahap, Sofyan Syafri. 2009. Critical Analysis of Financial Statements.Jakarta: Raja Grafindo Persada.

Hartono, Jogiyanto. 2007. Portofollio Theory and Investment Analysis, Third Edition. Yogyakarta: BPFE

Indonesian Institute of Accountants (IAI) .2016. Revised Financial Accounting Standards 2016. Salemba Empat. Jakarta.

Jogiyanto. 2007. Portfolio and Investment Analysis. BPFE. Yogyakarta.

Kusuma, I. L., \& Nawangsari, A. N. (2017). Analysis of Effect of Profitabilityand Managerial Ownershipon The Term of Delivery of Financial Reporton Soe Registered In Indonesia 2012 Stock Exchange 2012-2016. International Journal of Economics, Business and Accounting Research (IJEBAR), 1(02).

Sujarweni, V. Wiratna. (2017). Financial Statement Analysis: Theory, Application, \& Research Results. Yogyakarta: New Library Press.

Puspitasari, Ketut Dian and Lartini, Made Yani. 2014. The Effect of Company Size, Subsidiaries, Leverage, and KAP Size on Audit Delay. E-Journal of Udayana University Accounting.

Rochimawati. (2010). Audit Delay Discriminant Analysis in the Financial Industry on the Indonesia Stock Exchange (IDX) (IDX). Accounting Journal of the Faculty of Economics, Gunadarma University.

Setiawan, Heru. 2013. Effect of Company Size, Auditor Reputation, Audit Opinion, Profitability, Solvency Against Audit Delay on Financial Companies Listed on the Indonesia Stock Exchange (IDX). Thesis. Jakarta. Faculty of Economics and Business, Syarif Hidayatullah State Islamic University.

Kadir, Abdul. 2011. Factors that Influence Timeliness of Financial Reporting Empirical Studies in Manufacturing Companies in the Jakarta Stock Exchange. Journal of Management and Accounting. Vol 12, No. 1 Cashmere. 2013.

Financial Statement Analysis. Rajawali Press: Jakarta. Listyorini Wahyu Widati and Fina Septy 2008. Factors Affecting the Timeframe of Presentation of Financial Statements to the Public, Economic Focus (FE), Journal of Economic Focus. December 2008, pp. 173 187 Vol 7 No. 3. ISSN: 1412-3851.

Mouna, A and J. Anis. 2013. Financial Reporting Delay and Investors Behavior: Evidence from Tunisia. International Journal Management Business 3. 
Paransa, Rizki PJ, Azhari, Muhammad and Iradiyanty Aldilla. 2016. Analysis of the Effect of Profitability, Liquidity, Leverage, Company Size on Timeliness of Disclosure of Financial Statements of Companies Listed on the Indonesia Stock Exchange in the Mining Sector of Mineral and Metal Sub-Sector 2011-2014. E-Proceeding of Management. Vol.3, No.2 Page 1367. ISSN 2355-9357. Prasetyantoko, A. 2008. Corporate Governance; Institutional Approach. Jakarta: PT. Gramedia Main Library

Regina Christy Puspaningrum 1) Y. Djoko Suseno 2) Fortunately Sriwidodo. 2013. Analysis Of The Effect Of Financial Ratios Against Company's Profit Growth (Empirical Study on Food \& Beverages Companies Listed on the Indonesia Stock Exchange in 2009 2013). Journal of Human Resource Management Vol. 12 No. December 2, 2018: 169 183

Siegel, Joel G and Jae K. Shim, translated by Moh Kurdi. Dictionary of Accounting Terms. Jakarta: PT Elex Media Komputindo.1999. 